\title{
Diversity and social cohesion in the United Arab Emirates*
}

\author{
S.Z. Al Oraimi \\ United Arab Emirates University \\ P.O. Box 15551, Al Ain, Abu Dhabi, United Arab Emirates \\ (e-mail: s.aloraimi@uaeu.ac.ae)
}

\begin{abstract}
The article examines the effects of cultural diversity on social cohesion in the United Arab Emirates (UAE). The UAE is an oil-rich country established in 1971 as a federation of seven Emirates. It is a small state with a population of ten million; the citizens account only for $10 \%$ of the population. Oil wealth enables the country to achieve advanced levels of human, social and economic development. Recently, the UAE has experienced a massive social change; modernization processes have been impended on highest levels. However, due to the historical demographic structure of the local population, the UAE always depended on external labor forces. Skilled and unskilled male workers immigrate from neighboring countries; as a result, the population structure has changed. After the world economic depression in 2008, the UAE experienced a dramatic increase in the number of population. Professional workers from all over the world flowed to the country, and Dubai became a major center for the regional trade market; today, its free zones are considered the best technical base for service and logistic businesses. Today, more than 200 nationalities live in the country, and the majority of them are migrant male workers. This instable and unbalanced demographic structure created cultural domination - international cultures dominate the local one. The demographic imbalance between citizens and foreigners resulted in a kind of disharmony. Due to their feeling of being a minority, the Emiratis move from the old cities to the suburban areas, which creates many social tensions. All these circumstances affected social cohesion, communal harmony and the direct social interaction of cultural groups. To illustrate the tensions and discomforts in the UAE, the author presents the results of face-to-face interviews and a group discussion - as a critical analysis by those in the center of change.
\end{abstract}

Key words: society; culture; diversity; cohesion; citizens; immigrants; majority; minority

The article examines the influence of cultural diversity on social cohesion in the United Arab Emirates. The UAE is an oil-rich small country located in the Arab Gulf as traditional tribal sheikhdoms. Oil was discovered in 1968 in Abu Dhabi, and in 1971, these sheikhdoms came together to create a federation of seven emirates with the population of only 180326 . Economic prosperity allowed the country to achieve advanced levels of human, social and economic development: oil-revenues allow the federal government to provide free education, health care and housing system. However, with its limited population, the state could not implement the development projects and depended on neighboring countries, which made the UAE a dreamland for job seekers.

* (C) S.Z. Al Oraimi, 2020

The article was submitted on 26.05.2020. The article was accepted on 30.08.2020. 
The UAE current population is 10 million, and the citizens account only for $10 \%$ of it. In the last 50 years, millions of workers came to the country: 200 nationalities live in the UAE, most of them - male workers. Gradually, the national demographic structure changed the identity patterns. The article raises the question of whether the high share of immigrants affects the culture and traditions of the host country. The author conducted face-to-face interviews, group discussions and critical analysis. The qualitative method allowed the author, as an insider, to talk to people directly in honesty and confidentiality.

The sample of the research consisted of 15 respondents ( 8 men and 7 women) of the age 25-65. All participants are Emirati citizens of different social positions. Three men are government employees, one is retired, two have their own business, one is a teacher and one works in the media. Among women, one is a teacher, one is university professor, one is a school principal, one is retired, one is a housewife with a college degree, one is a government employee with a master degree, and one is a doctor. The discussion group consisted of 10 college students $(5$ men and 5 women) of the age of 19-22. The discussion was to identify direct interactions between young Emiratis and their perception of immigrants. Respondents were selected from two cities - Dubai and Abu Dhabi, while participants of the group discussion were selected from Al Ain college students. Data was collected in December 2019 (interviews) and July 2020 (group discussion).

The economy of the UAE is based on oil industry, trade markets and logistical services. As a rule, globalization controls capital and workforce; therefore, the country become a center of international business and foreign migration. Since the 1970s, the UAE have experienced radical changes, and the in-flow of migrants has increased - the population increased from 180326 to 277471 . In 1975, the population doubled to 55887 and immigrant workers accounted for 293788. Since the late 1970s, the number of immigrants increased gradually. For example, in 1980, the number of immigrants also doubled to 559960, in 1985, their number increased to 657400 , in 1990 - to 866300 , in 1995 - to 1.29 million, in 2016 - to 4.89 , in 2018 - to 7.38 (49\% in Dubai, 29.6\% in Abu Dhabi). This immigrant flow to the UAE is determined by the movement of international capital and labor force. For example, in 2008, many businesses moved from East Asia to the UAE. Headquarters of many global corporations are based in Dubai. Dubai hosts the majority of male workers for the construction development and real estate business.

According to Mesoudi, when $50 \%$ or more of the society are migrants, traditions cannot be preserved properly. Mesoudi believes that migrants can adapt to local traditions through social learning, and empirical studies prove that acculturation is common for the second generation, which shifts towards cultural values of the host society [7]. This argument works if migrants are a minority and the host country wants to integrate them in the national culture. In the UAE, the situation is different: migrants dominate the local culture because they are a majority; however, they can bring great benefits and contribute to the development of the country and its communities. According to Mehta, migrants do not destroy 
the West - it is destroyed by the fear of migrants due to its legacy of colonialism [6]. This argument cannot be applied to the UAE either for migrants exceed the local population by 9 times. Labor migrants changed the social structure of the UAE, affect social interaction and transform everyday culture.

In his analysis of Gramsci, Freire defines cultural hegemony as a tool of power domination which depends on education system, political system, natural resources and even the everyday vocabulary. He believes that cultural hegemony shapes political and social conflicts [3] — it is a tool by which one class controls other classes and creates systems dominated by the ideology. This statement explains the situation in the UAE where one group dominates the other. Gramsci mentioned that the dominant class believes in the approval of other classes and their acceptance of its leadership. Indeed, tolerance and acceptance are the most debated issues in the UAE.

According to Kathiravelu, there is always a situation of inequality - foreign workers' wages are extremely low; however, they can cope with the difficult circumstances of everyday life. Kathiravelu studied the social, economic and immigration status of international workers and defined Dubai as an example of inequality. She presents immigrants as victims nut ignores their influence on the local social environment (the majority of immigrants are male workers who live in the neighborhoods of the city center) [5]. The UAE government develops a special environment for immigrants to integrate them in all segments of society; at the same time, the UAE preserve and promote its unique traditions, culture and heritage, which becomes increasingly difficult given $90 \%$ of immigrants in the population.

Morgan stressed the relationship between demographic crisis and low fertility on the examples from Europe (Spain and Italy) [8]. By emphasizing the factor of fertility, Morgan makes me raise the same question about the situation in the UAE whether the demographic crisis is determined by the flows of migrants or by low fertility. I believe that in the UAE, the relationship between low fertility and the demographic crisis is invalid. The fertility rate in the UAE is sufficient; therefore, the demographic crisis has different causes, such as the unbalanced ratio of citizens and migrants. Gramsci studied the influence of the invisible power, and this idea is rooted in the Marxist theory, according to which ideology, beliefs and shared values reproduce class relations and conceal conflicts [4]. This idea explains the situation in the UAE: labor migrants as a majority have invisible power and can conceal contradictions. The situation is unpredictable; there are common interests of all migrant workers (for instance, salary increase) regardless of their differences.

Santucci explains that Gramsci's analysis of social conflict stressed the ability of the dominated class to achieve a better position in struggle [9]. He believes that the ability of any social class to achieve hegemony relies on its ability to unite intellectuals and absorb traditional literati of previous historical periods. The most important feature of every class seeking power is the struggle to represent and assimilate the ideology of traditional intellectuals. This assimilation takes place more quickly and effectively if the group makes further changes in its intellectuals' group. In the UAE, the question is who will get power - the minority or the 
majority. In general, the ability of identity to motivate belonging is bound by the cohesion. The UAE identity could meet these requirements provided enough space and time. This national identity should embrace Arab values and norms, and allow to respect and understand different foreign cultures. However, the fear of the demographic crisis foes not allow the equation 'internal-external' to work in the UAE. The local population growth does not coincide with the immigrant inflow there is no equilibrium. Indeed, with only $10 \%$ of the local population, the situation in the country is much beyond control [1].

D'Apollonia argues that immigration is not a new phenomenon; it has always been there. Today, there are multiple reasons for immigration, but the most important are education, work and family reunification. There are different motivations that cannot be limited to any domain. For instance, economic factors play a significant role in immigrants' mobility. Due to globalization, borders opened up for immigrant movements, in particular, from the less developed regions to the developed countries. Jobs shortage force people to emigrate to build their own futures [2]. There are different reasons for immigration to the UAE - famine, wars and lack of job opportunity force immigrants to accept minimum wages. Thus, the level of social diversity in the UAE is a major cause of social disharmony. Moreover, there is no social harmony among foreigners, because they came from different cultures and do not have common interests. Social interactions among immigrants are very limited, and between them and citizens are very rare. Many migrants cannot integrate into the society; while many citizens separate themselves from immigrants intentionally.

To alleviate social tensions, the state decided to promote tolerance and social acceptance, which reflects the economic policy and a parallel relationship between the presence of immigrants and the economic growth. Despite the fact that tolerance is a moral principle promoted by the state, broad-mindedness cannot reduce the level of tensions. Certainly, social pressures did not reach the level of conflicts immigrants and citizens live in pace. However, there are cultural barriers that prevent social cohesion. A male teacher said: "Social cohesion will never develop among 200 nationalities, and between 10\% of citizens and 90\% of immigrants. No balance or social unity is possible in the UAE. However, what is good about this unusual situation is that people live in peace albeit without cohesion. There is no social aggression, people accept the diversity and look at their daily life like a destiny... For us, it is a huge disaster to be $10 \%$ of the whole population".

People are fully aware of the demographic crisis. Some of them are critical and link the situation to the increasing number of immigrant workers. Young men are worried by the citizens' share of $10 \%$ and emphasize the challenges to the state sovereignty, state resources, traditions and national identity. Some respondents are worried about the future and the growing number of immigrants, highlight the effects of the mixed culture and languages on young generations, because group cultures divided the society into various subcultures and communities. A mid-age man expresses his thoughts as follows: "I am worried about the destructive impact 
on culture and social unity. Emiratis become a minority in their homeland and this situation never happened in history. There are many religious affiliations, ethnic groups and racial backgrounds, all of them live with us. We do not interact with them; I am afraid they do interact with us because they are a majority and can affect the culture. I do not want them to disappear; I just think about the future".

According to my experience as an internal observer, direct social interactions of foreigners and locals are limited to joint work. The number of foreign workers in the government sector is limited; most of them work in the private sector and free zones. Even if locals and foreigners work together, they isolate intentionally and built only job relations. Even schools and universities could not unify young generations or change their attitudes to each other. It seems that limited interactions and the variety of cultures created a huge social gap and weakened social cohesion. It became normal in the UAE for people to self-isolate in different neighborhoods and communities. A senior male said: "Why am I asked to communicate with others when I don't know their language? What do I tell them if I do not understand English? Even if I knew English, why would I change my own language? Even if they are my neighbors, they have their own lives, and I have my own life and traditions. My religion is different from them; they have their own beliefs; we are different. I do not hate anybody; the UAE is the land of tolerance - I just express my feelings".

Even under social separation, the Emiratis harbor fears; they are frustrated of culture diversity and 200 nationality living in their country. Some of they do not want immigrants to stay in the country for long. A mid-age man expressed concerns about immigrants who live in the UAE for more than 25 years - they have children and grandchildren. Generation after generation immigrants become a majority, which created a demographic gap between citizens and migrants and led to cultural problems: "The UAE society is based on a tribal unity; our social fabric cannot absorb other people, because they are different. Within tribal communities, people live secure and help each other. People love each other and are not aggressive. Today we have many people from different countries, and I feel very much alienated. The situation is very much terrifying".

People are also concerned about crimes. Many participants opened discussions about their old neighborhoods - these crowded areas become lodgings to single male workers and sources of social problems. Respondents believe that the UAE society has never known such frustrations before (drugs, law violations, etc.). A young woman said: "I will talk about aggression at schools; this type of violence is not rooted in our society. I am a teacher and I witness the change in my society. For example, bullying is a new phenomenon that came with immigrants; at schools, students learn bad behavior from their classmates and through social media".

The common concern of participants is the influence of immigrants on the local culture: respondents believe that patterns, norms and values of strangers harm the local society by creating a new culture with no specific face. Participants mentioned that the state allows an easy access to the country, and this strategy will affect the 
migration policy and lead to the national supremacy. A young woman argues: "The UAE is a liberal state that opened its borders for immigrants. Today, people from all over the world dominate our lives; today we are a minority in our country. Big modern cities, small towns and even remote villages - all are full of strangers with their cultures, values, languages, religions and behaviors".

Younger generation are worried about the future of their youth and children as shaped by the global lifestyles. Schools and universities adopt the global standard of teaching, foreign languages eliminate the native one, and the education system is westernized. Focus group participants say: "It is not a stereotype but true that immigrants are a source of social problems. In Dubai, the level of violence increased three times in two years. It is also true that our society is a source of tolerance and acceptance. In the past, it was rare to hear about crimes or violence; aggression is a new behavior related to strangers. It is also true that we live sideby-side with immigrants, but it is not true that citizens and strangers live in the social harmony. Social unity cannot exist among 200 nationalities; we are still an alienated minority. It is true that there is no social conflict in the UAE now, but no one can predict the future".

Participants also highlighted the national identity issue in the UAE and call the government to take serious measures in the education system considering the Arab language. Respondents believe that the current policies do not work well, and the state should reconsider the migration strategy. A young woman said: "We are Arabs and Muslims; our language and religion are important to us. We want to preserve our Arab identity; we want to be just like other nations who keep their languages and cultures. In the long term, the Emiratis will lose a sense of their national identity. Why should we change everything, even our way of life? I am scared of being alienated... The Emirati culture is deeply influenced; my children study at the English-speaking school; their Arabic is mixed-up with English - they speak English even at home".

Some respondents mention that today, there are different diseases and infections brought by immigrants. The health status of labor immigrants reflects their economic-social position - most of them have minimum wages and live in an unhealthy environment; while citizens and upper-class immigrants live in clean houses. However, the general social and health rules in the main cities changed. A female doctor explains: "Most Emiratis think about the influence of globalization on culture and demography, but they forget health and environment. Today, there is a high level of pollution in Dubai as a result of construction, pollution and manufacturing. There are also diseases and infections. People who live in 'poor' neighborhood' ignore health awareness and social security. Most workers lack decent healthy life and well-being. The international agencies who are responsible for hiring workers provide them with limited health services".

As a minority, the Emiratis are worried about the future of their country. They want the government to slow down the development processes to decrease the number of migrants. However, immigration is profitable for the state, while 
respondents mention no positive aspects of immigration - fear and anger dominate their feelings. The Emiratis do not reject foreigners in general, but they have concerns about single male labor migrants.

Acceptance and rejection are normal patterns of culture and rational-emotional reactions to others. As a rule, people do not trust others, who are alien to them or not bound by the same social relations. Usually, natives feel uncomfortable with strangers and do not trust them. Sometimes these feeling are followed by hatred if people try to protect themselves from outsiders and deny their rights to be a part of the society. Emiratis do not deny the rights of immigrants to live among them, but do not accept them as a majority. Since they are a minority, citizens try to selfisolate in certain areas away from the migrant zones. Despite the fact that immigrants are a majority, the local minority still has the power to reject and alienate immigrants.

The UAE citizens left the heart of old cities for remote areas, which led to their emotional and physical alienation from their heritage. Old cities are always foundations of legacy and full of memories. Emotionally, the young generation is detached from the deep values of the traditional culture, and, thus, is motivated by other cultures. Locals, the minority, live in remote areas far away from their old neighborhoods. Immigrants, the majority, live in old cities, close to old markets and old culture. Locals accuse foreigners of taking over old towns and distorting them. However, the destruction of old cities stared in the 1970s, when the state modernized the traditional urban structure - new cities emerged and no or little attention was paid to small old towns.

There are 200 nationalities in the UAE, most of them male workers divided by professions and work qualities. Historically, there were three waves of immigrants: the first wave of the late 1950s came from the neighboring countries such as Iran, Pakistan and India - immigrants were mainly merchants and entrepreneurs. They settled in Dubai and established their businesses. The second wave was in the 1970s - 1980s, after the discovery of oil and the creation of the state - immigrants mainly worked in Abu Dhabi, in the oil industry. In addition to unskilled workers, some experts came from Europe and the US to promote modernization. The third wave started in the 1990s and is still maintained by globalization - international business welcomes in the UAE job seekers from all over the world.

Now that different people from different nations settled in the UAE, a new social structure developed. Since immigrants differ by skills and work qualities, they form different social classes: upper, middle and lower. Each class has its own standards of living based on the level of education, position and income, which are reflected in residential areas and neighborhoods. Usually, the upper class lives in modern neighborhoods in the uptowns or near the seaside. Middle class lives in modern buildings in the center of cities close to the commercial areas. The lower class, usually single male workers, live in old towns or remote areas. This situation created a groupculture diversity; immigrants are divided into cohorts and lack social harmony.

Nevertheless, cultural barriers between citizens and immigrants are stronger than between different groups of immigrants. All foreigners have common interests 
and share a feeling of not being insiders. Usually, schools can unify different people; however, this kind of unity is typical for foreigners rather than with Emiratis. In the UAE, the school system is divided into public and private: locals go to the state schools and children of immigrants - to private schools. Thus, students from local and immigrant families do not have an opportunity to meet at school to learn from each other. Moreover, teaching languages and curriculums are not the same.

Furthermore, immigrant children born and raised in the UAE do not understated Arabic. They are neither introduced to the local society nor involved in the local culture. This disintegration is a long-term development; while its negative impacts emerged recently. However, even given the school segregation, some people believe that the young Emiratis are affected by international cultures and languages. Partly, this is true due to curriculums and learning materials.

In addition to the education system, cities and neighborhoods are also divided. The state provides subsidized homes to citizens in certain areas; thus, locals are separated from the rest of the population. Initially, this strategy limited interactions of all residents in the UAE society, which led to social segregation. Meanwhile, the demographic disparity created a huge social gap that has deepened with every step of newcomers and with each immigrant child born in the UAE.

Recently, the demographic crisis has worsened as a snowball. Perhaps, the decision-makers did not pay enough attention to the dilemma, but there is no available alternative. The UAE society has changed rapidly; such a transformation affected certain social structures. Respondents mentioned that local traditions fade away, and in the long run, it would be difficult for the state to preserve national identity, social cohesion and people's unity.

Million foreigners live in the UAE with their different cultures, languages, religions, national and ethnic identities. This situation made the state declare 2019 a year of tolerance and acceptance. The government is aware of the lack of social harmony. To avoid any potential conflict, the government tries to ensure social balance regardless of national differences. In 2016, the state adopted a principle of acceptance and established a new ministry of tolerance. However, with all its strategies of broad-mindedness, the country will not be able to eliminate all social pressures at once. The state cannot eliminate all failures at once, but it can postpone them for a while. The ministry of tolerance will not provide a radical immediate solution - it is a long-term process.

Culture domination, as mentioned by some respondents, is the dark face of globalization. In the UAE, this dominance takes different forms. It started with the group-culture diversity and ended up with the power hegemony. The cultural domination is not the result of only presence of strangers, but also the consequence of the power hegemony and political decisions. In addition, the global media have a great impact on both societies and national sovereignty. However, people do not differentiate the domination determined by globalization and the domination determined by the media and social influences of individuals and group-cultures. There are positive and negative coin-sides of group-cultures. Some respondents 
focused on the negative side and ignored the positive one. For instance, recently, the state has employed professional immigrants who have knowledge, experience and skills, who take efforts to learn local values and standards. Moreover, the very presence of immigrants challenges the locals and strengthen their social solidary. However, the worst scenario mentioned by respondents is that immigrants would control the state by getting access to power and resources.

Certainly, as a majority, the outsiders can influence the decision-making. Usually, the majority has strong hold over the society with strong stand on the ground. In the UAE, immigrants exceed citizens more than nine times, but have rather indirect influence on the state policies. The power is in the hands of the minority - the locals, who control positions, resources and decision-making. So far, the influence of immigrants does not go beyond the cultural domination of everyday life. The question is whether immigrants have power to threaten and undermine local decisions, to change the strategic planning of the state? According to Gramsci, if a group of people has power, they can dominant the entire society social institutions, beliefs, values and behaviors. This condition does not apply to the UAE. It is a welfare state, and the decision-makers control all facilities; immigrants do not have access to policy-making. They are permanent guests for a short period; even if some of them live in the UAE for a long time, they cannot influence decision-making.

However, people can have a hidden power - an invisible power with a visible influence. This argument can be applied to the UAE. Those who do not have power can still have influence. As a majority, immigrants can influence decision-making even without access to power, authority and control. Their culture dominates the society as a certain soft power. Logically, with little soft power or even without it, the dominant leading culture is the culture of the majority. Foreigners are there, and their presence is essential for the country - for implementing development projects on different levels. Their cultures, religions, values, norms and behaviors affect the persistence of the local culture. If the native people of the UAE wish for their culture to dominate the society, they have to be the majority. Will the UAE meet this condition? The answer is in between 'yes' and 'no': ether to be or not to be is the question.

The UAE lives in the dilemma of the unbalanced demographic structure - of locals and immigrants; therefore, international cultures and languages dominate the local ones. Citizens are still a minority and the share of immigrants grows. Social groups, values and behaviors are characterized by diversity and the lack of social cohesion. Despite this fact, the government tries to find a balance by changing policies and searching for alternatives. However, there is no easy choice left for the state to overcome the demographic crisis without revising development plans for promoting tolerance as a standard of acceptance would not result in social unity.

\section{References}

[1] Al Oraimi S.Z. UAE: Between Instilling Identity and Strengthening Belonging. Emirates Center for Strategic Studies and Research; 2018 (In Arabic).

[2] D'Appollonia A.C. Migrant Mobilization and Securitization in the US and Europe. How Does It Feel to Be a Threat? Palgrave Macmillan; 2015. 
[3] Freire P. Selections from the Prison Notebooks of Antonio Gramsci. New York; 1970.

[4] Heywood A. Political Ideas and Concepts: An Introduction. London; 1994.

[5] Kathiravelu L. Migrant Dubai: Low Wage Workers and the Construction of a Global City. Palgrave Macmillan; 2016.

[6] Mehta S. This Land Is Our Land: An Immigrant's Manifesto. Farrar, Straus and Giroux; 2019.

[7] Mesoudi A. Cultural Evolution: How Darwinian Theory Can Explain Human Culture and Synthesize the Social Sciences. Chicago University Press; 2011.

[8] Morgan S.P. Is low fertility a twenty-first-century demographic crisis? Demography. 2003; 4.

[9] Santucci A. Antonio Gramsci. New York; 2010.

\title{
Проблема социальных различий и социальной сплоченности в Объединенных Арабских Эмиратах*
}

\author{
С.3. Аль-Орайми \\ Университет Объединенных Арабских Эмиратов \\ 15551, Аль-Айн, Абу-Даби, ОАЭ \\ (e-mail: s.aloraimi@uaeu.ac.ae)
}

\begin{abstract}
Статья посвящена воздействию культурного разнообразия на уровень социальной сплоченности в Объединенных Арабских Эмиратах (ОАЭ). Эта богатая нефтью страна возникла в 1971 году как федерация семи эмиратов. Сегодня это небольшое государство, население которого составляет около 10 миллионов человек, а граждане - всего 10\%. Доходы от нефтедобычи позволили ОАЭ добиться высочайших показателей в социальном и экономическом развитии за недолгую историю своего существования. В последние десятилетия страна переживает серьезные социальные изменения, несмотря на то что модернизационные процессы блокируются на высочайших уровнях государственного управления. Дело в том, что по причине исторически сложившейся демографической структуры ОАЭ всегда зависели от внешней рабочей силы. Квалифицированные и неквалифицированные работники прибывают в страну из соседних государств, этот приток продолжается несколько десятилетий, что не могло не изменить социально-демографическую структуру ОАЭ. После всемирного экономического кризиса 2008 года и последовавшего за ним глобального экономического спада в ОАЭ резко выросла численность населения. Квалифицированные работники со всего мира устремились в страну, и Дубай стал основным центром региональной торговли - сегодня его свободные экономические зоны считаются лучшей технологической базой для предпринимательской активности в сфере услуг и логистики. В ОАЭ живут представители более двухсот национальностей, причем большинство из них - это трудовые мигранты-мужчины. Нестабильная и несбалансированная демографическая структура определяет особое культурное доминирование - национальные культуры мигрантов доминируют над местной культурой. Демографический перекос в пользу мигрантов в структуре населения ОАЭ порождает своего рода дисгармонию. Эмиратцы ощущают себя в собственной стране меньшинством и предпочитают переезжать из старинных городов в пригородную зону, что создает множество конфликтных ситуаций. Все перечисленное не может не сказываться на уровне социальной сплоченности, общинной идентичности и прямом социальном взаимодействии составляющих общество культурных групп. Чтобы показать накопившиеся в ОАЭ социальные различия и противоречия, автор представляет результаты личных интервью и групповой дискуссии, в которых критическую оценку сложившейся ситуации дают те, кто оказался в центре изменений.
\end{abstract}

Ключевые слова: общество; культура; сплоченность; граждане; мигранты; большинство; меньшинство

\footnotetext{
* (C) Аль-Орайми С.3., 2020

Статья поступила 26.05.2020 г. Статья принята к публикации 30.08.2020 г.
} 